Ambiente \& Água - An Interdisciplinary Journal of Applied Science
ISSN 1980-993X - doi:10.4136/1980-993X
www.ambi-agua.net
E-mail: ambi.agua@gmail.com

\title{
Physico-chemical technologies for nitrogen removal from wastewaters: a review
}

\author{
doi: 10.4136/ambi-agua.1618
}

Received: 08 Mar. 2015; Accepted: 21 May 2015

\author{
Andrea G. Capodaglio ${ }^{1}$; Petr Hlavínek ${ }^{2}$; Massimo Raboni ${ }^{3 *}$ \\ ${ }^{1}$ University of Pavia (UNIPV), Pavia, Italy \\ Department of Civil Engineering and Architecture \\ ${ }^{2}$ Brno University of Technology (BUT), Brno, Czech Republic \\ Institute of Municipal Water Management \\ ${ }^{3}$ Università Carlo Cattaneo (LIUC), Castellanza, Italy \\ "Corresponding author: e-mail: mraboni@liuc.it, \\ capo@unipv.it, hlavinek.p@fce.vutbr.cz
}

\begin{abstract}
The paper examines the main physico-chemical processes for nitrogen removal from wastewaters, considering both those that have been long known and still widely applied at the industrial scale, and those that are still at the research level. Special attention is paid to the latest technological developments, as well as to operational problems and fields of application. The processes considered are briefly summarized as follows: ammonia air and steam stripping; ammonia vacuum distillation; ammonia precipitation as struvite; ammonia and nitrate removal by selected ion exchange; breakpoint chlorination; chloramine removal by selected activated carbon; ammonia adsorption on charcoal; chemical reduction of nitrate; advanced oxidation processes to convert ammonia and organic-N into nitrogen gas or nitrate. Special attention is given to advanced oxidation processes, as great research efforts are currently addressed to their implementation. These specifically include ozonation, peroxon oxidation, catalytic wet air oxidation, photo-catalytic oxidation and electrochemical oxidation.
\end{abstract}

Keyword: nitrogen removal, physico-chemical technologies, wastewater treatment.

\section{Tecnologias físico-químicas para a remoção de nitrogênio das águas residuais: uma revisão}

\section{RESUMO}

O trabalho examina os processos físico-químicos para a remoção de nitrogênio das águas residuais, considerando, tanto os muitos conhecidos e amplamente aplicados em escala industrial, como aqueles que ainda estão em fase de pesquisa. Em particular, são enfatizados os desenvolvimentos tecnológicos mais recentes, bem como os problemas de operação e aplicação. Os processos considerados são resumidos da seguinte forma: extração de amoníaco com ar ou com vapor; destilação a vácuo de amoníaco; precipitação de amônia como estruvita; remoção de amônia e de nitrato por troca iônica selecionada; cloração ao breakpoint; remoção das cloraminas por carvão ativado seletivo; adsorção de amoníaco em carvão vegetal; redução química de nitrato; processos oxidativos avançados para converter 
amônia e N-orgânico em gás nitrogênio ou em nitrato. Deu-se especial atenção aos processos oxidativos avançados, tendo em vista que grandes esforços de pesquisa estão atualmente dirigidos à sua implementação. Eles incluem, especificamente: ozonização, oxidação com peroxono, oxidação catalítica por via úmida, oxidação foto-catalítica e oxidação electroquímica.

Palavras-chave: remoção de nitrogênio, tecnologias físico-químicas, tratamento de águas residuais.

\section{INTRODUCTION}

Human activities (e.g. communities, industrial plants, intensive livestock and farming, uncontrolled waste disposal) discharge many pollutants in water, including nitrogen (Urbini et al., 2015). Nitrogen is one of the causes of eutrophication, while some N-compounds (e.g., ammonia, ammonium, nitrite, nitrate, chloramines) can be harmful for human health. Nitrogen removal from wastewater can be achieved by biological or physico-chemical processes.

Biological processes are widely applied to the treatment of both municipal and industrial wastewaters. They are based on the action of heterotrophic bacteria that, under anoxic conditions, carry out the biochemical reduction of nitrate to nitrogen gas. At present, the dominant technology is pre-denitrification in activated sludge systems. Research advances in this field are mainly oriented to (i) evaluate the inhibiting effects of dissolved oxygen on denitrification rates (Raboni et al., 2014b; Torretta et al., 2014); (ii) limit, as much as possible, the presence of dissolved oxygen in the denitrification reactor (Urbini et al., 2015); (iii) highlight denitrification efficiency limitations in plants serving small communities due to strong fluctuations of the fed loads (Raboni et al., 2013a, Raboni et al., 2014a,c); (iv) evaluate the effects of the hydrodynamic behavior of the denitrification reactor (complete-mixing or plug-flow) on denitrification performance (Eramo et al., 1994; Farabegoli et al., 2003). With reference to industrial wastewaters, studies which highlight the inhibition effect of high ammonia concentrations on microbial activity ( $\mathrm{Li}$ and Zhao, 1999) suggest the use of alternative solutions based on physico-chemical processes.

Currently, a broad spectrum of physico-chemical technologies for the removal of nitrogen from wastewater is available: ammonia air and steam stripping; ammonia vacuum distillation; ammonia precipitation as struvite; ammonia and nitrate removal by selected ion exchange; breakpoint chlorination; chloramine removal by selected activated carbon; ammonia adsorption on charcoal; chemical reduction of nitrate; advanced oxidation processes to convert ammonia and organic- $\mathrm{N}$ into nitrogen gas or nitrate. The above-mentioned technologies are individually examined in this study to show both their applicability and actual viability in full-scale plants.

\section{TECHNOLOGIES REVIEW}

\subsection{Ammonia stripping and distillation}

Ammonia removal from highly concentrated wastewaters can be accomplished by air or steam stripping. Ammonia stripping is the best known with the most extensive applications in concentrated wastewater treatment (e.g. landfill leachate, supernatants of anaerobic digestion processes, specific flows of the petrochemical industry), while very few applications in sewage treatment are known. In ammonia stripping, lime or some other caustic substance is generally added to the wastewater until $\mathrm{pH}$ reaches 10.8-11.5 standard units, converting ammonium hydroxide ions to ammonia gas according to equilibrium reaction: 


$$
\mathrm{NH}_{4}{ }^{+}+\mathrm{OH}^{-} \leftrightarrows \mathrm{H}_{2} \mathrm{O}+\mathrm{NH}_{3} \uparrow
$$

The equilibrium is governed by $\mathrm{pH}$ and temperature, according to the equation describing the reaction's ionization constant $\left(K_{e q}\right)$

$$
K_{e q}=\frac{\left[\mathrm{NH}_{4}^{+}\right]\left[\mathrm{OH}^{-}\right]}{\left[\mathrm{NH}_{3}\right]}=1.8 \cdot 10^{-5} \quad \text { at } 25^{\circ} \mathrm{C}
$$

The equilibrium in water of the two nitrogenous forms (ammonia and ammonium ion) is well represented in Figure 1.

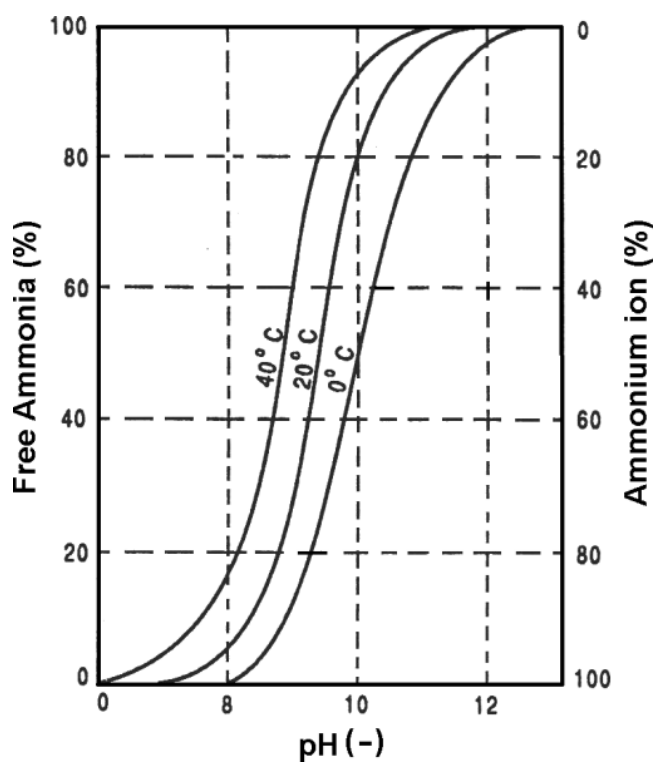

Figure 1. Free ammonia fraction as a function of temperature and $\mathrm{pH}$

Source: Culp and Culp (1971).

Efficiency of ammonia stripping depends mainly on $\mathrm{pH}$ and temperature, in addition to the dimensioning criteria of the process (e.g. liquid rate, air/liquid ratio, packing height, packing characteristics).

Air stripping is more common and more often applied than steam stripping, which is a quite similar process, with the difference that it requires operating temperatures higher than $95^{\circ} \mathrm{C}$ (Tchobanoglous et al., 2003). Steam stripping is usually adopted when ammonia recovery is economically attractive.

It should be considered that the resulting free dispersion of ammonia into the atmosphere may be unacceptable in many areas due to air quality concerns or regulations; in such cases, air stripping units are coupled with absorption towers which capture the released ammonia. In modern facilities, absorption onto sulfuric acid solutions allows the production of ammonium sulfate, which could constitute a marketable product (base fertilizer).

Figure 2 shows typical flow diagrams of the stripping process with air and steam.

Stripping is a relatively simple operation, as it only requires that $\mathrm{pH}$ and temperature remain stable enough. Its disadvantages are mainly related to the formation of $\mathrm{CaCO}_{3}$ scale on the tower packing, resulting in a progressive loss of stripping performance, with the need of frequent chemical cleaning operations (Viotti and Gavasci, 2015). Furthermore, air stripping cannot be performed in freezing conditions when icing of the lower packing strata may occur, resulting in a dramatic reduction of process performance. Closed loop systems are designed to 
avoid this risk. Air stripping is often used in the treatment of municipal solid waste (MSW) landfill leachate (or groundwater polluted by the same leachate). An example of the process is represented in Figure 3.

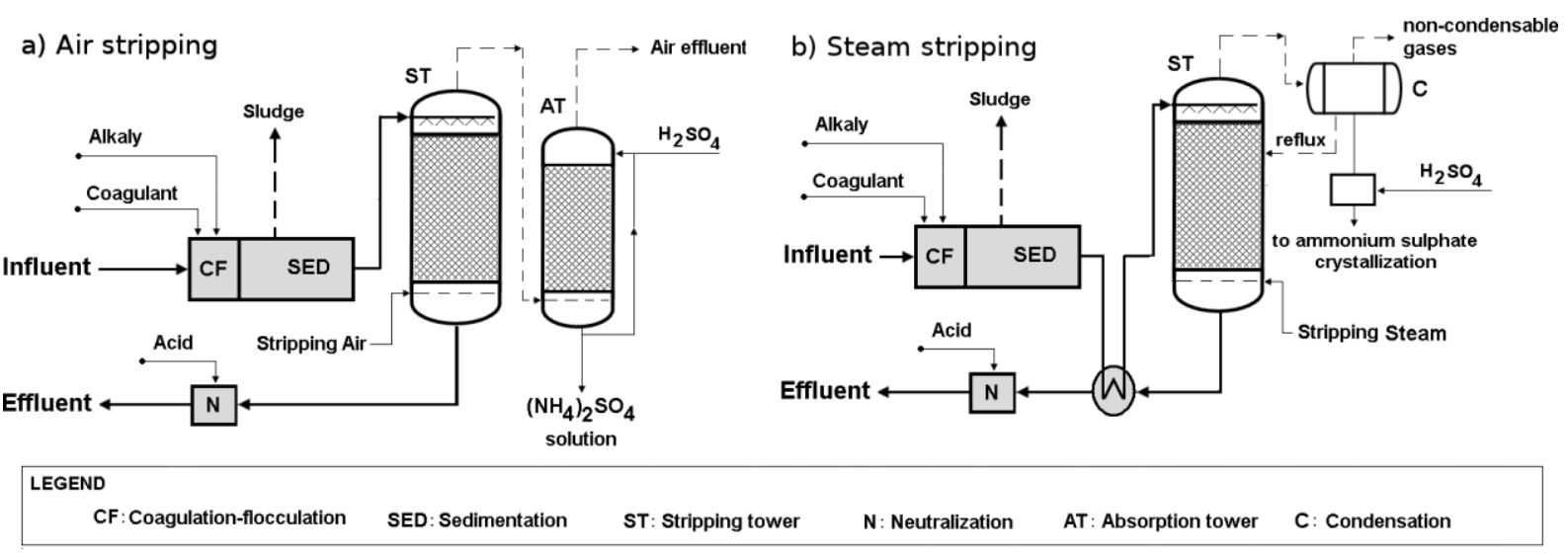

Figure 2. Typical flow diagrams of the stripping processes with air (a) and steam (b).

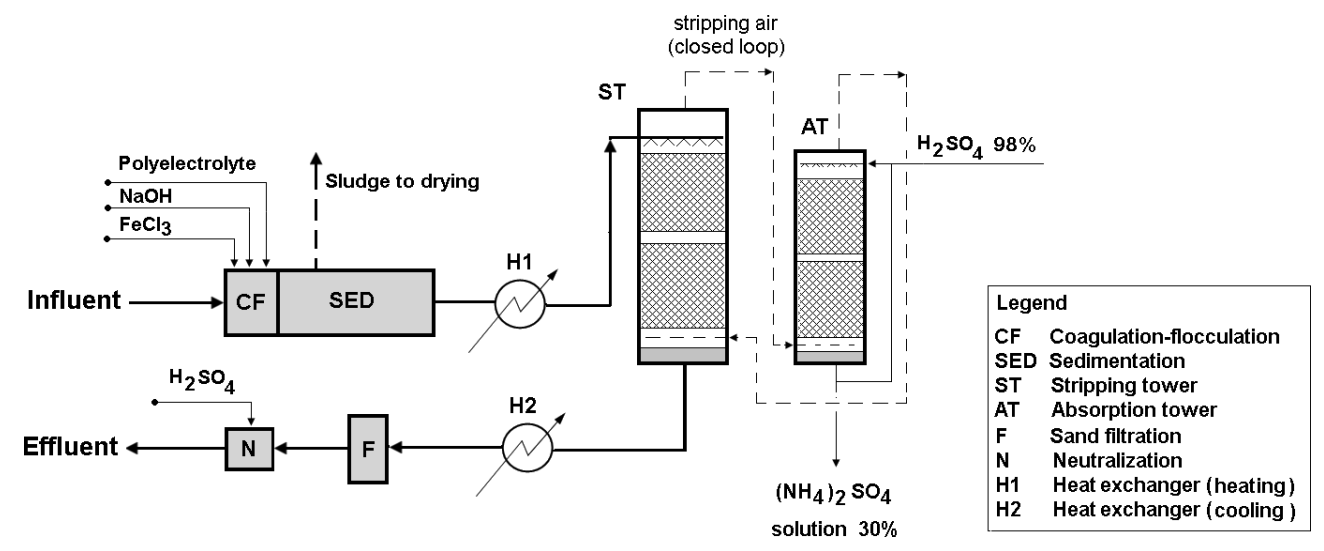

Figure 3. Diagram of a physico-chemical process for leachate treatment, with wastewater pre-heating and a closed-loop air stripping process.

Source: adapted from Raboni et al. (2013b).

The system consists of: coagulation-flocculation at $\mathrm{pH}>11$; water heating at $38^{\circ} \mathrm{C}$; ammonia air stripping; ammonia recovery by absorption with a sulfuric acid solution. Raboni et al. (2013b) obtained a reduction of ammonia from $199 \mathrm{mg} \mathrm{L}^{-1}$ (as N) down to $22.5 \mathrm{mg} \mathrm{L}^{-1}$ (as N). The plant showed severe scaling issues, with an increase in weight of the single filling components (Pall rings) up to seven times their original weight. The progressive scaling produced an $18 \%$ loss of ammonia removal efficiency, caused by the reduction of both the packing interfacial surface and the air/water ratio due to head loss increase. Periodical (every six months) chemical washing of the stripping towers with a $30 \% \mathrm{HCl}$ solution was carried out to avoid scaling build-up. Closed-loop air recirculation allowed the water temperature inside the column to be maintained in the range of $25-38^{\circ} \mathrm{C}$, even during winter, but caused a gradual decrease of the solution's $\mathrm{pH}$ within the tower. This was due to the acidic characteristics of the stripping air coming from the ammonia absorption tower. Subsequent experiences proved the actual possibility of achieving high ammonia removal efficiencies (greater than $95 \%$ ) by operating the stripping towers at $38^{\circ} \mathrm{C}$ with liquid rates below $4.5 \mathrm{~m}^{3} \mathrm{~m}^{-}$ ${ }^{2} \mathrm{~h}^{-1}$ and air/water ratios above $1,500 \mathrm{Nm}^{3} \mathrm{~m}^{-3}$ (Viotti and Gavasci, 2015).

Vacuum distillation is another viable solution for ammonia recovery (US-EPA, 2013). This process can be justified in case of highly concentrated streams and when waste heat is 
available. Vacuum flash distillation processes (Figure 4) have been applied to ammonia recovery from centrate of manure digested sludge, using as heat source the biogas generated by the anaerobic digestion (Orentlichter et al., 2009).

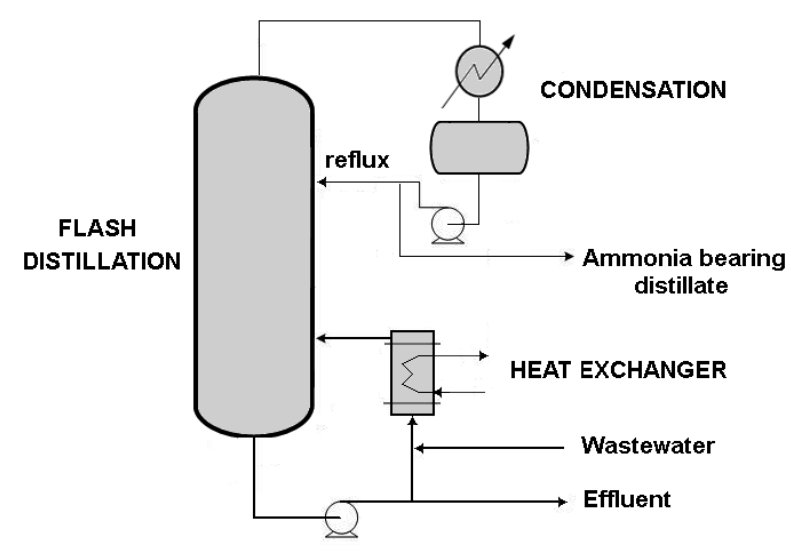

Figure 4. Diagram of a typical flash distillation process for ammonia recovery.

By operating the process at $\mathrm{pH}=9.5$ and $60^{\circ} \mathrm{C}$ under vacuum, an ammonia removal of approximately $1,000 \mathrm{mgNH}_{3}-\mathrm{N} \mathrm{L}^{-1}$ to less than $100 \mathrm{mgNH}_{3}-\mathrm{N} \mathrm{L}^{-1}$ can be achieved (Orentlichter et al., 2009). Other combinations of temperature and $\mathrm{pH}$ achieve similar high free ammonia fractions, allowing an effective stripping process. The resulting ammonia-rich distillate is a marketable product or it can be converted into an ammonium sulfate solution. If desired, such a solution can be further concentrated, using multiple vacuum distillation stages. According to pilot-scale results obtained with digested sludge liquor and landfill leachate at various concentrations, the process behaves according to a first order kinetics with respect to ammonia concentration, so it can be expected to provide $90 \%$ removal over a wide range of influent ammonia concentrations (Orenlichter, 2012).

\subsection{Ammonia precipitation as struvite}

Precipitation of $\mathrm{NH}_{4}{ }^{+}-\mathrm{N}$ as Magnesium Ammonium Phosphate (MAP), also named struvite (Figure 5), has been studied and implemented for different types of wastewaters, such as tannery effluents of leather industries (Tünay et al., 1997), digester supernatant (Siegrist et al., 1994; 1996; Celen and Turker, 2001) and in industrial wastewater treatment plants, from coke plants and nitrogen works to pig farms (Zdybiewska and Kula, 1991; Nelson et al., 2003), sludge liquor (Schulze-Rettmer, 1999) and landfill leachate (Prater, 2014). The reaction is as follows:

$$
\mathrm{Mg}^{2+}+\mathrm{PO}_{4}{ }^{3-}+\mathrm{NH}_{4}{ }^{+}+6 \mathrm{H}_{2} \mathrm{O} \leftrightarrows \mathrm{MgNH}_{4} \mathrm{PO}_{4} \cdot 6 \mathrm{H}_{2} \mathrm{O} \downarrow
$$

MAP has low water solubility $\left(0.169 \mathrm{~g} \mathrm{~L}^{-1}\right.$ at $\left.25^{\circ} \mathrm{C}\right)$ and can be easily separated from the water phase. Since the molecular weight of MAP is $245 \mathrm{~g} \mathrm{~mol}^{-1}, 17.5 \mathrm{~g} \mathrm{MgNH}_{4} \mathrm{PO}_{4} \cdot 6 \mathrm{H}_{2} \mathrm{O}$ are theoretically formed as precipitate when $1 \mathrm{~g}$ of $\mathrm{NH}_{4}{ }^{+}-\mathrm{N}$ is removed. Because MAP has a similar composition of $\mathrm{Mg}, \mathrm{P}$ and $\mathrm{N}$ found in guano, it can be used in lieu of commercial fertilizers.

The basic chemical reactions for MAP formation are reported as follows ( $\mathrm{Li}$ et al., 1999): 


$$
\begin{aligned}
& \mathrm{MgCl}_{2} \cdot 6 \mathrm{H}_{2} \mathrm{O}+\mathrm{Na}_{2} \mathrm{HPO}_{4} \cdot 12 \mathrm{H}_{2} \mathrm{O}+\mathrm{NH}_{4}^{+} \leftrightarrows \mathrm{MgNH}_{4} \mathrm{PO}_{4} \cdot 6 \mathrm{H}_{2} \mathrm{O} \downarrow+2 \mathrm{NaCl} \\
& \mathrm{MgO}+\mathrm{H}_{3} \mathrm{PO}_{4}+\mathrm{NH}_{4}^{+} \rightarrow \mathrm{MgNH}_{4} \mathrm{PO}_{4} \cdot 6 \mathrm{H}_{2} \mathrm{O} \downarrow+\mathrm{H}_{2} \mathrm{O} \\
& \mathrm{Ca}\left(\mathrm{H}_{2} \mathrm{PO}_{4}\right)_{2} \cdot \mathrm{H}_{2} \mathrm{O}+\mathrm{MgSO}_{4} \cdot 7 \mathrm{H}_{2} \mathrm{O}+\mathrm{NH}_{4}^{+} \rightarrow \mathrm{MgNH}_{4} \mathrm{PO}_{4} \cdot 6 \mathrm{H}_{2} \mathrm{O} \downarrow+\mathrm{CaSO}_{4} \downarrow
\end{aligned}
$$

Struvite precipitation is controlled by $\mathrm{pH}$ and temperature, and can be influenced by impurities (e.g. calcium). Crystal formation proceeds by nucleation from crystal embryos followed by their growth, and their precipitation will not occur without nucleation (Kim et al., 2007).

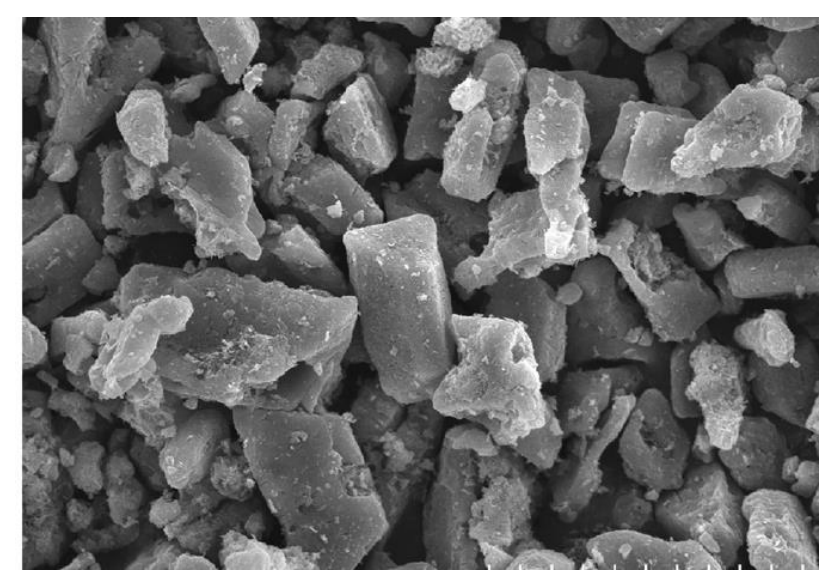

Figure 5. Electron microscopy imaging of MAP precipitates.

Source: Zhang et al. (2009).

Zhang et al. (2009) showed that ammonium in landfill leachate could be removed at the optimum $\mathrm{pH}$ of 9.5 . The molar ratio $\mathrm{Mg}^{2+}: \mathrm{NH}_{4}{ }^{+}: \mathrm{PO}_{4}{ }^{3-}$ was controlled at $1.15: 1: 1$ to remove ammonium effectively and avoid higher concentrations of $\mathrm{PO}_{4}{ }^{3-}$ in the effluent.

Magnesium chloride $\left(\mathrm{MgCl}_{2}\right)$ is the most commonly used reagent in these cases. However, Huang et al. (2010) used magnesite as a low-cost magnesium source for the treatment of rare-earth elements separation process wastewaters. Since magnesite solubility is low, prior to use it was decomposed to magnesia, which has a higher reaction rate.

The cost of adding magnesium salts is the major economic constraint to the application of struvite crystallization for nutrient recovery. Lee et al. (2003) report the removal of nitrogen and phosphate from wastewater by addition of bittern, the salt produced by evaporation of seawater which is a byproduct of salt manufacture. Bittern is a low-cost source of magnesium ions because contains mostly magnesium chloride (approximately $32 \mathrm{~g} \mathrm{~L}^{-1}$, or 27 times that of seawater) with smaller amounts of other inorganic compounds. The effectiveness of bittern as a precipitant, in relation to magnesium chloride and seawater, was evaluated at different $\mathrm{pH}$ 's, with results slightly lower than those of alternative $\mathrm{Mg}^{2+}$ sources.

The most-used industrial reactor technologies for struvite precipitation are fluidized bulk reactors and stirred tanks, the latter being the easiest to set-up and operate. Fluidized bulk reactors are harder to control since they need steady flow to keep the bulk fluidized. Some proprietary industrial processes are currently being commercialized. Figure 6 shows the diagram of a process for struvite precipitation with a fluidized reactor applied in a full scale plant in USA (Garcia-Belinchón et al., 2013; Hazen and Sawyer, 2010). 


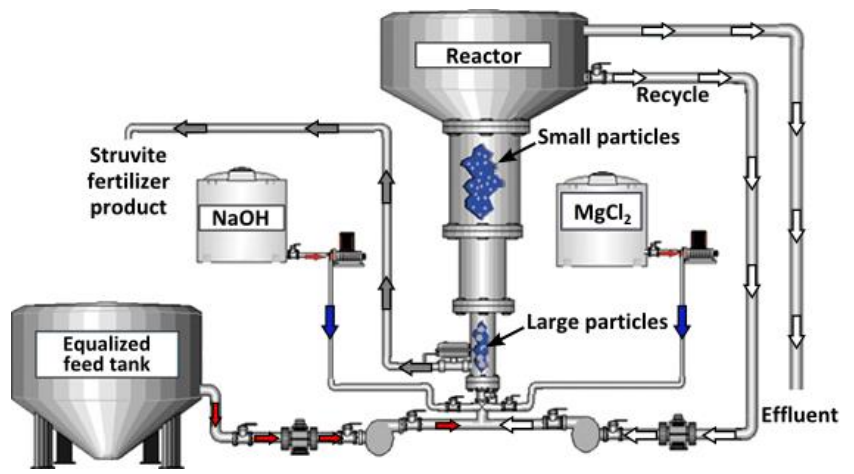

Figure 6. Diagram of the process for struvite precipitation and recovery.

Source: adapted from Hazen and Sawyer (2010).

$\mathrm{NaOH}$ and $\mathrm{MgCl}_{2}$ are added to the concentrate liquor (supernatant of a sludge digester with high $\mathrm{N}$ and $\mathrm{P}$ content). The resulting solution is fed to the fluidized reactor. The upper part consists of a clarification stage while the lower cylindrical parts are the stages in which struvite precipitates. Small MAP particles aggregate progressively up to form large particles which drop on the bottom of the reactor, where they are collected and reused as fertilizer.

\subsection{Ion exchange for ammonia and nitrate removal}

Ion exchange using zeolites is a technologically simple process for ammonia removal. Zeolites have a porous structure that can accommodate a wide variety of cations (e.g. $\mathrm{Na}^{+}, \mathrm{K}^{+}$, $\mathrm{Ca}^{2+}, \mathrm{Mg}^{2+}$ and others). Zeolite minerals differ in $\mathrm{Si}$ and $\mathrm{Al}$ content. Natural zeolites (aluminosilicates) particularly used are clinoptilolite and modernite. Clinoptilolite, the most common and abundant high-siliceous zeolite ( $\mathrm{Si}$ :Al ratio equal to 5.7) is usually employed as ion exchange medium. It has a two-dimensional channel system that allows the mineral to act as a molecular sieve. For this reason it has high sorption and ion-exchange capacity, ion exchange selectivity, catalytic activity and structural temperature stability up to $700-750^{\circ} \mathrm{C}$ (Zabochnicka-Świątek and Malinska, 2010). Synthetic zeolites are also produced and they have some key advantages over their natural analogs, as they are manufactured in a uniform, phase-pure state. The main raw materials used to manufacture zeolites are silica and alumina, which are among the most abundant mineral components on earth; therefore the potential to supply synthetic zeolites is virtually unlimited.

The mechanism of ammonia-nitrogen removal by clinoptilolite is based on cationic ion-exchange. But ammonia can be also removed through adsorption in the structural pores of the zeolite. The efficiency of ammonia removal is strongly affected by temperature: the higher the temperature, the higher the removal efficiency achieved. Regarding $\mathrm{pH}$, the removal capacity of clinoptilolite is approximately constant between 4 and 8, diminishing rapidly outside this range (US-EPA, 1971a,b). Clinoptilolite and other zeolite minerals easily adsorb potassium, ammonia, calcium, sodium, magnesium and other ions. Therefore, high cationic concentration of the solution will reduce ammonia removal capability.

In demonstration studies on municipal wastewaters containing about $20 \mathrm{mgNH}_{3}-\mathrm{N} \mathrm{L}^{-1}$, an average ammonia removal of $95.7 \%$ was reached (US-EPA, 1971a,b). Another important advantage of zeolite applied to water treatment is its high porosity when compared to other minerals: this results in good hydrodynamic properties (head loss through zeolite filters is 1.5-2.0 times smaller than that in sand filters) and adsorption properties; furthermore its high capacity allows for adsorption of other contaminants (e.g. phytoplankton and bacteria).

Both natural and synthetic zeolites can be regenerated with solutions containing high concentrations of calcium ions. The regenerant is a relatively small volume of liquid with high ammonia concentrations. Ammonia-rich eluate can be stripped, recovered by chemical 
absorption or destroyed by electrolysis producing chlorine which reacts with the ammonia to produce nitrogen gas (Figure 7).

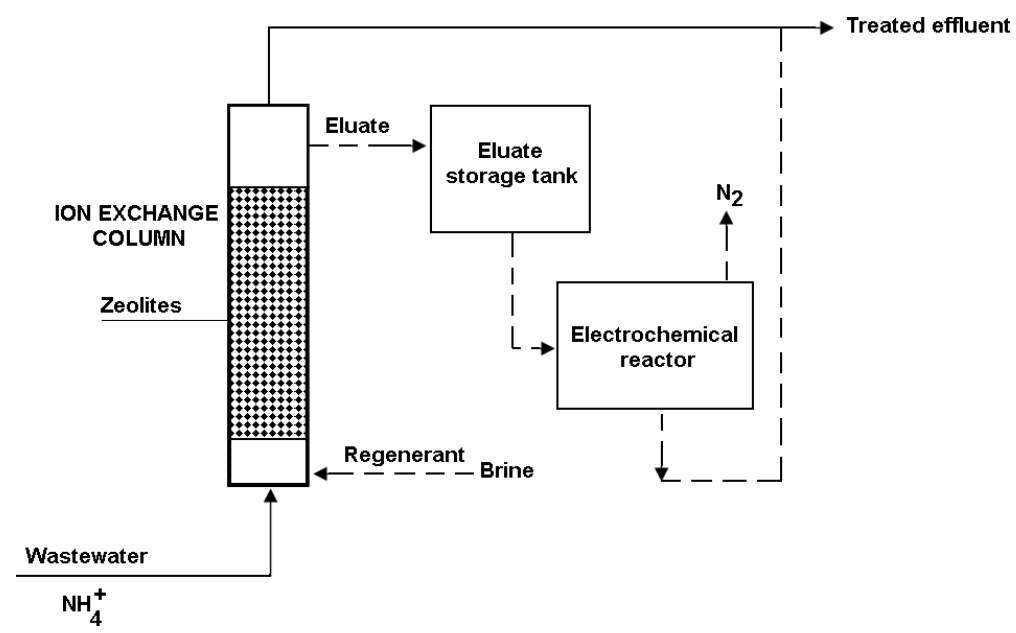

Figure 7. Simplified diagram of a ion exchange process on a zeolite bed for ammonia removal. Ammonia in the eluate is decomposed to nitrogen gas by an electrochemical reaction.

Rozic et al. (2000) investigated the removal of ammonium ions from aqueous solutions using a combination of natural clay and zeolite. Clays and zeolites are both hydrated aluminosilicates, but they have different crystalline structure. Zeolites consist of symmetrically stacked alumina and silica tetrahedra forming an open and stable three dimensional honeycomb structure with negative charge, while clays are extremely fine alluminosilicates crystals or particles. Because of their fineness, clays exhibit the chemical properties of colloids and structurally appear as "sandwiches" of tetrahedral and octahedral sheet structures. Rozic et al. found that zeolite removes more than $50 \%$ (in weight) of ammonia nitrogen, while clay must be added in a liquid colloidal state in order to increase the specific surface area and to obtain maximum efficiency. A further process is required to be performed on the effluent as a consequence of the adding of colloidal clay.

Jorgensen and Weatherley (2003) evaluated the effects of organic contaminants in synthetic wastewater, showing that in most cases their presence enhances the uptake of ammonium onto the ion exchangers. Rahmani et al. (2004) demonstrated successfully removal of ammonia from synthetic solutions using Semnan clinoptilolite samples from northern Iran. They showed that the total exchange capacity of such zeolite for three different mesh sizes was between 17.31 to $18.98 \mathrm{mgNH}_{4}{ }^{+} \mathrm{g}^{-1}$ of dry weight. Zeolite particles with mesh 40 gave an ammonia adsorption capacity higher than other, coarser ones, indicating that smaller particle sizes have higher ion-exchange capacity thanks to the greater available surface area. They also demonstrated that the ammonia adsorption capacity of the Semnan clinoptilolite remained constant after multiple regenerations with $\mathrm{NaCl}$.

The ion exchange process is also effective at removing nitrates. Applications of this type are mainly in the field of water supply using synthetic resin beads. Since conventional anion exchange resins have a higher affinity for sulfate and other anions, nitrate-selective strong base anion resins with triethylamine or tributylamine functional groups were developed.

Ethyl groups force nitrate selectivity over sulfate demonstrating to remove over $90 \%$ of nitrates present in water. Such resins are regenerated with $\mathrm{NaCl}$ or $\mathrm{KCl}$. Purolite ${ }^{\mathrm{TM}}$ type resins have also shown the ability to remove arsenic and nitrate (Wang et al., 2011). A model of the process is reported in the literature (Kim and Benjamin, 2004). 


\subsection{Chemical oxidation of ammonia}

\subsubsection{Ammonia and chloramines removal by activated carbon}

Activated carbon (AC) is commonly used for the adsorption of ammonia gas, while the aqueous phase adsorption is generally considered ineffective due to ammonia's strong affinity with water. Adsorption of aqueous ammonia is obtained with bamboo charcoal carbonized at $400^{\circ} \mathrm{C}$, subsequently treated with diluted sulfuric acid to enhance its adsorption properties (Asada et al., 2006). Its adsorption capacity is evaluated through an adsorption isotherm, in about $8.5 \mathrm{mg}$ ammonia $\mathrm{g}^{-1}$ charcoal in correspondence of an ammonia equilibrium concentration of $5 \mathrm{mg} \mathrm{L}^{-1}$.

Formation of chloramines, and their subsequent removal by activated carbon, is well known. Chloramines are formed by adding chlorine or its by-products to a water with some ammonia content. The reactions are:

$$
\begin{aligned}
& \mathrm{HOCl}+\mathrm{NH}_{3} \rightarrow \mathrm{NH}_{2} \mathrm{Cl}+\mathrm{H}_{2} \mathrm{O} \text { (monochloramine) } \\
& \mathrm{HOCl}+\mathrm{NH}_{2} \mathrm{Cl} \rightarrow \mathrm{NHCl}_{2}+\mathrm{H}_{2} \mathrm{O} \text { (dichloramine) } \\
& \mathrm{HOCl}+\mathrm{NHCl}_{2} \rightarrow \mathrm{NCl}_{3}+\mathrm{H}_{2} \mathrm{O} \text { (nitrogen trichloride) }
\end{aligned}
$$

The formation of the specific chloramines depends on both the $\mathrm{pH}$ and the $\mathrm{Cl}_{2}: \mathrm{NH}_{4}{ }^{+}$ molar ratio (Tchobanogolous et al., 2003). At pH 7-8 and $\mathrm{Cl}_{2}: \mathrm{NH}_{4}{ }^{+}>1.8$ dichloramine is dominant; viceversa, with $\mathrm{Cl}_{2}: \mathrm{NH}_{4}{ }^{+}<0.7$ the monochloramine is largely prevalent.

Chloramines possess disinfectant power, like chlorine, but they have a negative impact on the taste and odor of water, and some toxicological impact on human health. Therefore, their removal by $\mathrm{AC}$ is commonly practiced in drinking water treatment plants and, in a few cases, also in sewage treatment plants for the protection of receiving waters' ecosystems.

The reactions of $\mathrm{AC}$ with residual chlorine and dichloramine can be summarized as follows:

$$
\begin{aligned}
& A C+2 \mathrm{Cl}_{2}+2 \mathrm{H}_{2} \mathrm{O} \rightarrow 4 \mathrm{HCl}+\mathrm{CO}_{2} \\
& A C+4 \mathrm{NHCl}_{2} \rightarrow 2 \mathrm{~N}_{2}+\mathrm{CO}_{2}+8 \mathrm{H}^{+}+8 \mathrm{Cl}^{-}
\end{aligned}
$$

Hence, AC does not really adsorb chloramines but acts as a catalyst for their chemical breakdown. This catalytic reaction involves formation of an oxide of carbon intermediate $\left(\mathrm{CO}^{*}\right)$. Fine mesh sizes of AC remove chloramines more efficiently than coarse ones, since they have greater surface area, and allow faster access to the catalytic sites. Also, selected AC with increased sites for $\mathrm{CO}^{*}$ formation improves chloramine removal. When using new $\mathrm{AC}$, an initial dosing with chlorine to pre-oxidize the carbon may result in a more effective chloramine removal (WQA, 2013). In order to improve AC's adsorption capacity of chloramines and chlorine, new types of surface-enhanced, catalytic AC were manufactured. These catalytic carbons are marketed with a peroxide number (rate of hydrogen peroxide decomposition), in addition to the traditional iodine number. With these new products the minimum empty bed contact time (EBCT) has been reduced to $3 \mathrm{~min}$, while for classical ACs the minimum EBCT's need to be greater than $10 \mathrm{~min}$.

\subsubsection{Breakpoint chlorination for ammonia removal}

Breakpoint chlorination is a widely used process that oxidizes ammonia to nitrogen gas, thus removing it from wastewaters. This process is practical only as an effluent polishing technique, not for the removal of high levels of nitrogen. When chlorine is added to 
wastewater containing ammonia-nitrogen, it initially reacts with hypochlorous acid to form chloramines. Continued addition of chlorine after "breakpoint" (occurring when free chlorine residual is formed) converts chloramines to nitrogen gas. The overall breakpoint reaction is given as:

$$
\mathrm{NH}_{4}{ }^{+}+1.5 \mathrm{HOCl} \rightarrow 0.5 \mathrm{~N}_{2} \uparrow+1.5 \mathrm{H}_{2} \mathrm{O}+2.5 \mathrm{H}^{+}+1.5 \mathrm{Cl}^{-}
$$

Stoichiometrically, a $\mathrm{Cl}_{2}: \mathrm{NH}_{3}-\mathrm{N}$ weight ratio of $7.6: 1$ is required to oxidize ammonia to nitrogen gas. Figure 8 shows a theoretical breakpoint curve.

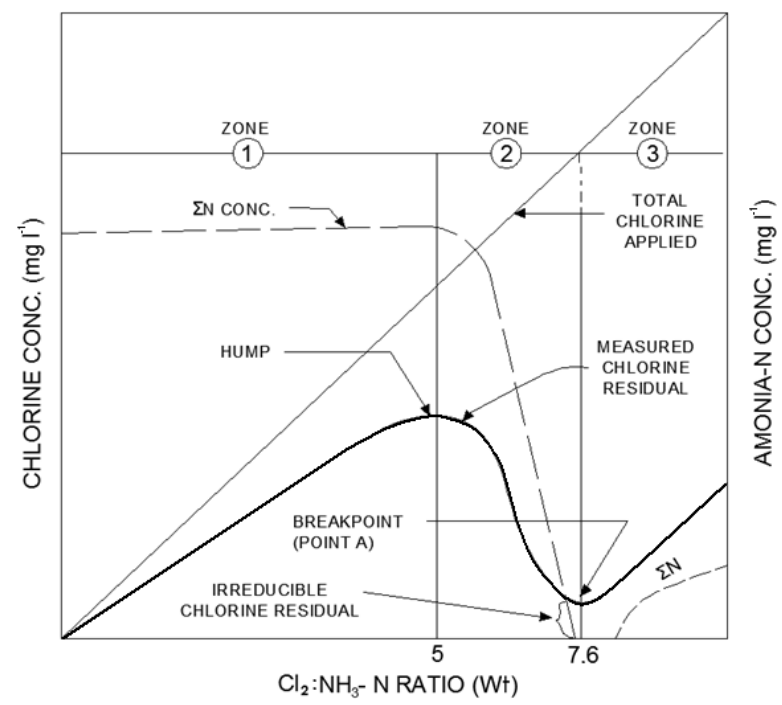

Figure 8. Theoretical breakpoint curve.

Source: White (1992).

Zone 1 is associated with the reactions of chlorine and ammonia to form monochloramine; Zone 2 is associated with an increase in dichloramine and the disappearance of $\mathrm{NH}_{3}$; Zone 3 is associated with the appearance of free chlorine after the breakpoint. Ammonia concentration begins to decline at about $\mathrm{Cl}_{2}: \mathrm{NH}_{3}$ ratio equal to 5, until it becomes nearly completely absent at the breakpoint. It is generally accepted that, as applied chlorine increases from 0 up to the "hump" in the curve (Zone 1), monochloramine is being formed. The declining portion of the breakpoint curve is where dichloramine is formed, and then decomposes to yield nitrogen gas, resulting in a decline of the ammonia nitrogen concentration.

Design of the mechanical components of a breakpoint chlorination system is quite simple. The first reaction between ammonia and chlorine occurs rapidly, and no special design features are necessary, except providing for complete, uniform mixing of the chlorine with the wastewater. A minimum contact time of 10 minutes is a good practice. Sizing the chlorine-producing and feed device depends on the influent ammonia concentration, as well as on the degree of treatment that the wastewater has received. As the quality of influent to the breakpoint process improves, the required amount of chlorine decreases, and approaches the theoretical amount required to oxidize ammonia to nitrogen. If insufficient chlorine to reach the breakpoint is added, there is no nitrogen gas formation, and formed chloramines have to be destroyed prior to discharge.

Design should include provisions to continuously monitor the effluent for free chlorine residual following its addition, and to pace the rate of chlorine feed to maintain a set-point free chlorine residual. When using breakpoint chlorination, attention should be paid to the possible formation of excess acid (that some wastewaters do not neutralize), and to the elimination from the effluent of the active chlorine residual by dechlorination. Theoretically, 
$14.3 \mathrm{mg} \mathrm{L}^{-1}$ of alkalinity as $\mathrm{CaCO}_{3}$ is required to neutralize the acid $(\mathrm{HCl})$ produced by the oxidation of $1 \mathrm{mg} \mathrm{L}^{-1}$ of ammonia-nitrogen gas. To maintain $\mathrm{pH}$ above 6.3, at least twice this theoretical alkalinity is needed. Except for wastewaters already possessing high alkalinity, and treatment systems using lime coagulation prior to chlorination, design normally includes the means to feeding an alkaline chemical to the wastewater stream, to maintain $\mathrm{pH}$ in the proper range. The $\mathrm{pH}$ should be monitored carefully and continuously. In fact, a simple $\mathrm{pH}$ increase will not correct the problem: if $\mathrm{pH}$ rises above 8 , breakpoint will be reached only very slowly. If $\mathrm{NaOCl}$ is used instead of $\mathrm{Cl}_{2}$, the alkalinity requirement is reduced by $75 \%$. Dechlorination may be required as a companion process to breakpoint chlorination (WEF, 2009).

\subsubsection{Advanced oxidation processes}

Many advanced chemical oxidation processes for the conversion of ammonia and $\mathrm{N}$ organic into nitrogen gas or nitrate have been proposed and applied: ozonation, peroxone oxidation, catalytic wet air oxidation, photocatalityc oxidation, and electrochemical oxidation.

Ozonation is one of the methods for the oxidation of low concentration of ammonia into nitrate. The reaction can be expressed as:

$$
\mathrm{NH}_{3}+4 \mathrm{O}_{3} \rightarrow \mathrm{H}^{+}+\mathrm{NO}_{3}{ }^{-}+\mathrm{H}_{2} \mathrm{O}+4 \mathrm{O}_{2}
$$

However, since the persistence of ozone in water is quite short (its half-life is about 15 min at $298 \mathrm{~K}$, and $\mathrm{pH}=7$ ), its rate of reaction with ammonia is slow.

A more advanced oxidation using ozone and hydrogen peroxide mixtures as combined oxidants (known as peroxone oxidation) may also be effective for ammonia removal from wastewaters.

The combined kinetics of traditional ozonation and peroxone (hydrogen peroxide mixtures) oxidation of ammonia in alkaline solutions was also studied (Chiang-Hai et al., 1997). The ozonation reaction is governed by the direct oxidation of ammonia with ozone molecules. The overall kinetics is second order, with first order each in ozone and ammonia.

Khuntia et al. (2012) found that the ozonation using a pilot plant with micro-bubbles instead of a traditional system increased the removal efficiency of ammonia thanks to (i) a larger gas-liquid interfacial area; (ii) slower bubble rising velocity; (iii) longer persistence; (iv) smaller amount of ozone required due to the generation of hydroxyl radicals responsible for pollutants oxidation. In fact, the solubility of ozone in water is several times higher than that of oxygen. Therefore, when a mixture of ozone and oxygen is passed into water in the form of micro-bubbles, ozone preferentially dissolves in water. Li et al. (2009) reported that free hydroxyl radicals are generated from collapsing oxygen micro-bubbles under strongly acidic conditions. As a consequence, the possibility of ammonia oxidation by these radicals increases. The authors also found that aqueous ammonia was effectively oxidized by ozone micro-bubbles under alkaline conditions (i.e., $\mathrm{pH}>7$ ), even at low concentrations (e.g., $1 \mathrm{mgNH}_{3} \mathrm{~L}^{-1}$ ). Micro-bubble-aided ozonation is a fast process and can be used for water treatment at large scales, and at a wide $\mathrm{pH}$ range. After ozonation is complete, ozone self-decomposes to oxygen without introducing any new pollutant into the water, and leaving only the products of oxidation.

Catalytic wet air oxidation (CWAO) consists of oxidizing pollutants with oxygen at high pressure $\left(5-200\right.$ bar) and temperature $\left(125-320^{\circ} \mathrm{C}\right)$ in the presence of a catalyst (e.g. oxides, noble metals). This process is applied to the treatment of liquid waste particularly rich in complex organic compounds. Several applications to chemical and petrochemical waste liquors are known. Among the nitrogenous organic compounds that can be treated by CWAO are aniline and its azoic derivatives: nitrotoluenesulfonic acid, nitrobenzene, dinitrotoluene, quinoline, nitrophenol, fenuron, acenaphtene, acetonitrile, carbamide, nitromethane, etc. 
CWAO is able to achieve the complete mineralization of organic pollutants (into $\mathrm{CO}_{2}, \mathrm{~N}_{2}$ and $\mathrm{H}_{2} \mathrm{O}$ ), but in some cases the efficiency of the process is controlled at a lower level, in order to simply increase effluent's biodegradability. In general, also most of the non-catalytic techniques (WAO, $\mathrm{O}_{3} / \mathrm{H}_{2} \mathrm{O}_{2}, \mathrm{O}_{3} / \mathrm{UV}$ ) can be applied, but to obtain significant conversions of nitrogenous organic products, they need to operate with a large excess of oxidants. CWAO processes have been applied to the elimination of ammonia with a good efficiency, particularly when associated with the use of cobalt (II) oxide $(\mathrm{CoO})$ as a catalyst at temperatures up to $260^{\circ} \mathrm{C}$. Aguilar et al. (2003) studied the oxidation of aqueous ammonia to nitrogen by CWAO process with $\mathrm{AC}$ as catalyst, confirming that ammonia conversion to nitrogen is favored by hydrogenated ACs in which the most acidic groups had been eliminated.

Photocatalytic oxidation of aqueous ammonia (into $\mathrm{NO}_{2}^{-}$and $\mathrm{NO}_{3}^{-}$) over microwave-induced Titanate $\left(\mathrm{Na}_{\mathrm{x}} \mathrm{H}_{2-\mathrm{x}} \mathrm{Ti}_{3} \mathrm{O}_{7}\right)$ NanoTubes (TNTs) was investigated (Ou et al., 2008). Photocatalytic oxidation of $\mathrm{NH}_{3} / \mathrm{NH}_{4}{ }^{+}$over $\mathrm{TiO}_{2}$ is a promising process due to its inherent stability and high photocatalytic potential. TNTs have received much attention due to their one-dimensional nanostructure and versatile applications, including solar cell photocatalysis, and electroluminescent hybrid devices. Some researchers consider TNTs effective photocatalysts for pollutant' degradation (Tsai and Teng, 2004). A selective photocatalytic oxidation of $\mathrm{NH}_{3}$ to $\mathrm{N}_{2}$ on platinized $\mathrm{TiO}_{2}$ in water was also investigated, achieving 80\% ammonia removal efficiency (Lee et al., 2002).

Electrochemical oxidation of ammonia has attracted attention in recent years since it addresses both clean energy supply $\left(\mathrm{CO}_{2}\right.$ free $)$ and environmental protection. In general, ammonia can be transformed to other nitrogen forms by direct anodic oxidation, or indirect oxidation in an electrochemical process. Direct oxidation at a reasonable reaction rate according to the chemical reactions 14,15 , and 16 implies many advantages; however, large-scale applications have been strongly hindered by insufficient performance, and by the high cost of electrodes. In an indirect oxidation process, strong oxidants $(\mathrm{HClO}$ and $\bullet \mathrm{OH})$ are first produced in the bulk of solution via electrochemical reactions. Subsequently, these oxidants destroy the ammonia by oxidation reactions.
(Anode reaction)
$2 \mathrm{NH}_{3(\mathrm{aq})}+6 \mathrm{OH}^{-} \rightarrow \mathrm{N}_{2}+6 \mathrm{H}_{2} \mathrm{O}+6 \mathrm{e}^{-}$
(Cathode reaction)
$6 \mathrm{H}_{2} \mathrm{O}+6 \mathrm{e}^{-} \rightarrow 3 \mathrm{H}_{2}+6 \mathrm{OH}^{-}$
(Overall reaction)
$2 \mathrm{NH}_{3(\mathrm{aq})} \rightarrow \mathrm{N}_{2}+3 \mathrm{H}_{2}$

Active components of electrodes include pure Pt, Pt-based alloys, and Pt-free metal oxide, such as $\mathrm{Ni} / \mathrm{Ni}(\mathrm{OH})_{2}$, $\mathrm{IrO}_{2}$, etc. Despite the high catalytic activities of Pt and Pt-alloys for electrochemical oxidation of ammonia, the high cost of these electrodes limits their application at an industrial scale. Hence, Pt-free electrodes provide an alternative for accelerating its application. Electrochemical oxidation of ammonia over a Pt-free, $\mathrm{Ru}-\mathrm{Ir} / \mathrm{TiO}{ }_{2}$ anode under continuous flow conditions was evaluated (He et al., 2015). The commercial anode was effective for ammonia removal by electro-oxidation at neutral $\mathrm{pH}$ in a continuous electrochemical reactor, and provided $80 \%$ removal of ammonia in a packed bed reactor, under optimum conditions, proving to be a suitable, economic alternative for the treatment of ammonia wastewater with high chloride concentration. 


\subsection{Chemical reduction of nitrate}

Nitrate is a weak oxidizing ion; therefore, in order to react with reducing agents and produce nitrogen gas or ammonia, it requires the presence of a catalyst or improved thermodynamic conditions (pressure and temperature). For this purpose, reducing agents that have been experimentally applied under (i) acidic condition are: formic acid, iron metal, methanol and ammonium ion; (ii) alkaline conditions are: aluminum, zinc, iron, iron (II), ammonia, hydrazine, glucose, and hydrogen (Fanning, 2000). More recently, a chemical process capable of converting nitrate ions into environmentally neutral nitrogen gas was proposed. Nitrate-contaminated water is put in contact with sulfamic acid and zinc at $\mathrm{pH}$ 2.0-3.5. Sulfamic acid acts as reducing agent of nitrous ion, while $\mathrm{Zn}$ promotes nitrate reduction. The advantages of this process are its low cost, the absence of limitations by nitrate concentration levels and its lack of sensitivity to other contaminants (Seungmoon et al., 2006). Thus it may be applied to high strength wastewater from optoelectronic, fertilizer, pharmaceutical, food and dairy industries. Chemical denitrification depends on the $\mathrm{pH}$ as well as the $\mathrm{Zn}$, sulfamic acid and nitrate concentrations (i.e. high $\mathrm{Zn}$ concentration increases the nitrate removal rate).

\section{CONCLUSIONS}

Physico-chemical processes have long been widely applied for the removal of nitrogen from wastewater. Among them, ammonia air stripping is perhaps the most widespread. It is typically applied to the treatment of wastewaters with high ammonia concentration (i.e. digested sludge liquor; landfill leachate; specific wastewater streams from chemical and petrochemical industries). In leachate treatment, ammonia removal efficiencies higher than 95\% can be achieved. Recently, the process is often coupled to ammonia absorption onto sulfuric acid, yielding a solution that could constitute a marketable product (base fertilizer). Stripping is a relatively simple operation. Its disadvantages are mainly related to the formation of calcium carbonate scale in the packing of stripping towers and the icing of the lower packing strata in freezing conditions, resulting in the progressive loss of performance. Solutions can be the packing chemical cleaning with strong acidic solutions and closed loop air recirculation, respectively. In a few cases, ammonia removal and recovery is achieved by steam stripping or vacuum distillation processes. Breakpoint chlorination (ammonia converted into nitrogen gas) and activated carbon adsorption of chloramines are long known for their applications, mainly in the field of surface water potabilization. Currently, great interest is attached to ammonia precipitation as struvite (magnesium ammonium phosphate) from concentrated wastewater (e.g. digested sludge liquor; landfill leachate). Magnesium chloride is the most commonly used reagent, but other low cost magnesium salts can be used with some efficiency loss. A few proprietary industrial processes are currently being commercialized. Ion exchange processes for ammonia and nitrate removal have certain diffusion, but they are mainly confined to (clean) water treatment. Clinoptilolite is often applied for ammonia removal, while specifically manufactured strong anion-based resins with triethylamine or tributylamine functional groups have proven to be effective in nitrate removal, achieving over $90 \%$ efficiency. Other resins have demonstrated the ability to simultaneously remove arsenic and nitrate. Great attention is currently given to advanced chemical oxidation processes for the conversion of ammonia and $\mathrm{N}$-organic into nitrogen gas or nitrate. Some of these processes (e.g. ozonation; peroxone oxidation; catalityc wet air oxidation) have already been applied in real scale applications, while others (e.g. photocatalytic oxidation, electrochemical oxidation; nitrate chemical reduction), although very promising, are still confined to the level of applied research. 


\section{REFERENCES}

AGUILAR, C.; GARCIA, R.; SOTO-GARRIDO, G.; ARRIAGADA, R. Catalytic wet air oxidation of aqueous ammonia with activated carbon. Applied Catalysis B: Environmental, v. 46, n. 2, p. 229-237, 2003. http://dx.doi.org/10.1016/S09263373(03)00229-7

ASADA, T.; OHKUBO, T.; KAWATA, K.; OIKAWA, K. Ammonia adsorption on bamboo charcoal with acid treatment. Journal of Health Science, v. 52, n. 5: p. 585-589, 2006. http://dx.doi.org/10.1248/jhs.52.585

CELEN, I.; TÜRKER, M. Recovery of ammonia as struvite from anaerobic digester effluents. Environmental Technology, v. 22, n. 11, p. 1263-1272, 2001.

http://dx.doi.org/10.1080/09593332208618192

CHIANG-HAI K.; YUAN, F.; HILL D. O. Kinetics of oxidation of ammonia in solutions containing ozone with or without hydrogen peroxide. Industrial \& Engineering Chemistry Research, v. 36, p. 4108-4113, 1997. http://dx.doi.org/10.1021/ie9702082

CULP, R. L.; CULP, G. L. Advanced wastewater treatment. New York: Van Nostrand Reinhold, 1971. 310 p.

ERAMO, B.; GAVASCI, R.; MISITI, A.; VIOTTI, P. Validation of a multisubstrate mathematical model for the simulation of the denitrification process in fluidized bed biofilm reactors. Water Science and Technology, v. 29, n. 10-11, p. 401-408, 1994.

FANNING, J. C. The chemical reduction of nitrate in aqueous solution. Coordination Chemistry Reviews, v. 199, n. 1, p. 159-179, 2000. http://dx.doi.org/10.1016/S00108545(99)00143-5

FARABEGOLI, G.; GAVASCI, R.; LOMBARDI, F.; ROMANI, F. Denitrification in tertiary filtration: application of an up-flow filter. Journal of Environmental Science and Health - Part A Toxic/Hazardous Substances and Environmental Engineering, v. 38, n. 10, p. 2169-2177, 2003. http://dx.doi.org/10.1081/ESE-120023349

GARCIA-BELINCHÓN, C.; RIECK, T.; BOUCHY, L.; GALÍ, A.; ROUGÉ, P.; FÀBREGAS, C. Struvite recovery: pilot-scale results and economic assessment of different scenarios. Water Practice and Technology, v. 8, n. 1, p. 119-130, 2013.

http://dx.doi.org/10.2166/wpt.2013.013

HAZEN AND SAWYER ENIRONMENTAL ENGINEERS \& SCIENTISTS. New process makes asset of phosphorus and nitrogen from wastewater. 2010. Available in: $<$ http://www.hazenandsawyer.com/news/new-process-makes-asset-of-phosphorus-andnitrogen-from-wastewater>. Access in: May 2015.

HE, S.; HUANG, Q.; ZHANG, Y.; WANG, L.; NIE, Y. Investigation on Direct and Indirect Electrochemical Oxidation of Ammonia over $\mathrm{Ru}-\mathrm{Ir} / \mathrm{TiO}_{2}$ Anode. Industrial \& Engineering Chemical Research, v. 54, n. 5, p. 1447-1451, 2015. http://dx.doi.org/10.1021/ie503832t

HUANG, H. M.; XIAO, X. M.; YANG, L. P.; YAN, B. Removal of ammonium as struvite using magnesite as a source of magnesium ions. Water Practice \& Technology, v. 5, n. 1, 2010. http://dx.doi.org/10.2166/wpt.2010.007 
JORGENSEN, T. C.; WEATHERLEY, L. R. Ammonia removal from wastewater by ion exchange in the presence of organic contaminants. Water Research, v. 37, n. 8, p. 1723-1728, 2003. http://dx.doi.org/10.1016/S0043-1354(02)00571-7

KIM, D.; RYU, H. D.; KIM, M. S.; KIM, J.; LEE, S. I. Enhancing struvite precipitation potential for ammonia nitrogen removal in municipal landfill leachate. Journal of Hazardous Materials, v. 146, n. 1-2, p. 81-85, 2007.

http://dx.doi.org/10.1016/j.jhazmat.2006.11.054

KIM, J.; BENJAMIN, M. M. Modeling a novel ion exchange process for arsenic and nitrate removal. Water Research, v. 38, n. 8, p. 2053-2062, 2004. http://dx.doi.org/10.1016/j.watres.2004.01.012

KHUNTIA, S.; MAJUMDER, S. K.; GHOSH, P. Removal of ammonia from water by ozone microbubbles. Industrial \& Engineering Chemical Research, v. 52, n. 1, p. 318-326, 2012. http://dx.doi.org/10.1021/ie302212p

LEE, J.; PARK, H.; CHOI, W. Selective photocatalytic oxidation of $\mathrm{NH}_{3}$ to $\mathrm{N}_{2}$ on platinized $\mathrm{TiO}_{2}$ in water. Environmental Science \& Technology, v. 36, n. 24, p. 5462-5468, 2002. http://dx.doi.org/10.1021/es025930s

LEE, S. I.; WEON, S. Y.; LEE, C. W.; KOOPMAN, B. Removal of nitrogen and phosphate from wastewater by addition of bittern. Chemosphere, v. 51, n. 4, p. 265-271, 2003. http://dx.doi.org/10.1016/S0045-6535(02)00807-X

LI, X. Z.; ZHAO, Q. L. Inhibition of microbial activity of activated sludge by ammonia leachate. Environmental International, v. 25, n. 8, p. 961-968, 1999. http://dx.doi.org/10.1016/S0160-4120(99)00068-9

LI, X. Z.; ZHAO, Q. L.; HAO, X. D. Ammonium removal from landfill leachate by chemical precipitation. Waste Management, v. 19, n. 6, p. 409-415, 1999. http://dx.doi.org/10.1016/S0956-053X(99)00148-8

LI, P.; TAKAHASHI, M.; CHIBA, K. Enhanced free-radical generation by shrinking microbubbles using a copper catalyst. Chemosphere, v. 77, n. 8, p. 1157-1160, 2009. http://dx.doi.org/10.1016/j.chemosphere.2009.07.062

NELSON, N.O.; MIKKELSEN, R. L.; HESTERBERG D. L. Struvite precipitation in anaerobic swine lagoon liquid: effect of $\mathrm{pH}$ and $\mathrm{Mg}: \mathrm{P}$ ratio and determination of rate constant. Bioresource Technology, v. 89, n. 3, p. 229-236, 2003. http://dx.doi.org/10.1016/S0960-8524(03)00076-2

ORENTLICHER, M.; BROWN, S.; HALL, C. Centrate ammonia reduction with ARP®: pilot data with synthetic and actual wastewaters. WEF/WERF NUTRIENT REMOVAL SPECIALTY CONFERENCE, 2009, New York. Proceedings... New York: WEF; WERF, 2009. p. 546-555

ORENTLICHER, M. Overview of nitrogen removal technologies and application/use of associated end products. GOT MANURE TRADESHOW AND CONFERENCE, March 2012, New York. Proceedings... New York: Cornell University, 2012. p. 27-29.

OU, H. H.; LIAO, C. H.; LIOU, Y. H.; HONG, J. H.; LO, S. L. Photocatalytic oxidation of aqueous ammonia over microwave-induced titanate nanotubes. Environmental Science \& Technology, v. 42, n. 12, p. 4507-4512, 2008. http://dx.doi.org/10.1021/es703211u 
PRATER. J. Improved production of magnesium ammonium phosphate (struvite) from landfill leachate - Final report. Stevens Point: University of Wisconsin, 2014. 98 p.

RABONI, M.; TORRETTA, V.; URBINI, G. Influence of strong diurnal variations in sewage quality on the performance of biological denitrification in small community wastewater treatment plants (WWTPs). Sustainability, v. 5, n. 9, p. 3679-3689, 2013 a. http://dx.doi.org/10.3390/su5093679

RABONI, M.; TORRETTA, V.; VIOTTI, P.; URBINI, G. Experimental plant for the chemico-physical treatment of groundwater polluted by MSW leachate, with ammonia recovery. Revista Ambiente \& Agua, v. 8, n. 3, p. 22-32, 2013b. http://dx.doi.org/10.4136/ambi-agua. 1250

RABONI, M.; TORRETTA, V.; VIOTTI, P.; URBINI, G. Pilot experimentation with complete mixing anoxic reactors to improve sewage denitrification in treatment plants in small communities. Sustainability, v. 6, n. 1, p. 112-122, 2014a.

http://dx.doi.org/10.3390/su6010112

RABONI, M.; TORRETTA, V.; VIOTTI, P.; URBINI, G. Calculating specific denitrification rates in pre-denitrification by assessing the influence of dissolved oxygen, sludge loading and the mixed-liquor recycle. Environmental Technology, v. 35, n. 20, p. 2582-2588, 2014b. http://dx.doi.org/10.1080/09593330.2014.913690

RABONI, M.; GAVASCI, R.; URBINI, G. UASB followed by sub-surface horizontal flow phytodepuration for the sustainable treatment of the sewage generated by a small rural community. Sustainability, v. 6, n. 10, p. 6998-7012, 2014 c.

http://dx.doi.org/10.3390/su6106998

RAHMANI, A. R.; MAHVI, A. H.; MESDAGHINIA, A. R.; NASSERI, S. Investigation of ammonia removal from polluted waters by Clinoptilolite zeolite. International Journal of Environmental Science \& Technology, v. 1, n. 2, p. 125-133, 2004. http://dx.doi.org/10.1007/BF03325825

ROZIC, M.; CERJAN-STEFANOVIC, S.; KURAJICA, S.; VANCINA, V.; HODZIC, E. Ammoniacal Nitrogen Removal from Water by Treatment with Clays and Zeolites. Water Research, v. 34, n. 14, p. 3675-3681, 2000. http://dx.doi.org/10.1016/S00431354(00)00113-5

SCHULZE-RETTMER, R. The simultaneous chemical precipitation of ammonium and phosphate in the form of magnesium-ammonium-phosphate. Water Science \& Technology, v. 23, n. 4-6, p. 659-667, 1999.

SEUNGMOON, L.; SANJEEV, M.; JUNG-HWA, J.; KWINAM, P.; JIN-WON, P. Development of physicochemical nitrogen removal process for high strength industrial wastewater. Water Research, v. 40, n. 5., p. 975-980, 2006.

http://dx.doi.org/10.1016/j.watres.2006.01.018

SIEGRIST, H.; GAJCY, D.; SULZER, S.; ROELEVED, P.; OSCHWALD, R.; FRISCHKNECHT, $H$. et al. Nitrogen elimination from digester supernatant with magnesium-ammonium-phosphate precipitation. In: Chemical water and wastewater treatment II. Berlin Heidelberg: Springer, 1994. p. 457-465. 
SIEGRIST, H. Nitrogen removal from digester supernatant - comparison of chemical and biological methods. Water Science \& Technology, v. 34, n. 1-2, p. 399-406, 1996. http://dx.doi.org/10.1016/0273-1223(96)00529-X

TCHOBANOGLOUS, G.; BURTON, F. L.; STENSEL, H. D. Wastewater engineering treatment and reuse. $4^{\text {th }}$ Ed. New York: Mc Graw Hill, 2003.

TORRETTA, V.; RAGAZZI, M.; TRULLI, E.; DE FEO, G.; URBINI, G.; RABONI, M.; RADA, E. C. Assessment of biological kinetics in a conventional municipal WWTP by means of oxygen uptake rate method. Sustainability, v. 6, n. 4, p. 1833-1847, 2014. http://dx.doi.org/10.3390/su6041833

TSAI, C. C.; TENG, H. Regulation of the physical characteristics of titania nanotube aggregates synthesized from hydrothermal treatment. Chemistry of Materials, v. 16, $\mathrm{n}$. 22, p. 4352-4358, 2004. http://dx.doi.org/10.1021/cm049643u

TÜNAY O., KABDASLI, I.; ORHON, D.; KOLÇAK, S. Ammonia removal by magnesium ammonium phosphate in industrial wastewaters. Water Science \& Technology, v. 36, n. 2-3, p. 225-228, 1997. http://dx.doi.org/10.1016/S0273-1223(97)00391-0

URBINI, G.; GAVASCI, R.; VIOTTI, P. Oxygen control and improved denitrification efficiency by means of a post-anoxic reactor. Sustainability, v. 7, n. 2, p. 1201-1212, 2015. http://dx.doi.org/10.3390/su7021201

UNITED STATES. Environmental Protect Agency - US-EPA. Wastewater ammonia removal by ion exchange. Washington DC, 1971a. 111 p. (Water Pollution Control Research Series 17010 ECZ 02/71.)

UNITED STATES. Environmental Protect Agency - US-EPA. Optimization of ammonia removal by ion exchange using clinoptilolite. Washington DC, 1971b. 192 p. (Water Pollution Control Research Series 17080 DAR 09/71)

UNITED STATES. Environmental Protect Agency - US-EPA. Emerging Technologies for wastewater treatment and in-plant wet weather management. Washington DC, USEPA, 2013. 188 p. (EPA 832-R-12-011.)

VIOTTI, P.; GAVASCI, R. Scaling of ammonia stripping towers in the treatment of groundwater polluted by the leachate of municipal solid waste landfill: study of the causes and the effects on the stripping performance. Revista Ambiente \& Agua, v. 10, n. 2, p. 240-252, 2015. http://dx.doi.org/10.4136/ambi-agua.1567

WANG, L.; CHEN, A. S. H.; WANG, A.; CONDIT, W. E. Arsenic and nitrate removal from drinking water by ion exchange. Cincinnati: US-EPA. 2011. 138 p. (EPA/600/R-11/040.)

WATER ENVIRONMENT FEDERATION - WEF. Design of municipal wastewater treatment plants - manual of practice 8. $5^{\text {th }}$ ed. New York: McGraw-Hill Professional, 2009. 2600 p.

WATER QUALITY ASSOCIATION - WQA. Chloramine Fact Sheet. Lisle: WQA. 2013. 5 p.

WHITE, G. C. Handbook of Chlorination. $3^{\text {rd }}$ ed. New York: Van Nostrand Reinhold Co., 1992. 
ZABOCHNICKA-ŚWIĄTEK, M.; MALIŃSKA, K. Removal of ammonia by clinoptilolite. Global NEST Journal, v. 12, n. 3, p. 256-261, 2010.

ZDYBIEWSKA, M. W.; KULA, B. Removal of ammonia nitrogen by the precipitation method, on the example of some selected waste waters. Water Science \& Technology, v. 24, n. 7, p. 229-234, 1991.

ZHANG, T.; DING, L.; REN, H. Pretreatment of ammonium removal from landfill leachate by chemical precipitation. Journal of Hazardous Materials, v. 166, n. 2-3, p. 911-915, 2009. http://dx.doi.org/10.1016/j.jhazmat.2008.11.101 